\title{
Potential roles of berries in the prevention of breast cancer progression
}

\author{
Patricia Reboredo-Rodríguez ${ }^{\mathrm{a}, \mathrm{b}, *}$ \\ ${ }^{a}$ Dipartimento di Scienze Cliniche Specialistiche ed Odontostomatologiche (DISCO)-Sez. Biochimica, \\ Facoltà di Medicina, Università Politecnica delle Marche, Ancona, Italy \\ ${ }^{\mathrm{b}}$ Department of Analytical and Food Chemistry, Nutrition and Bromatology Group, Faculty of Science, \\ University of Vigo, Ourense Campus, Ourense, Spain
}

Received 8 November 2018; accepted 8 November 2018

\begin{abstract}
Breast cancer (BC) encompasses a collection of different diseases characterized by different biological and pathological features, clinical presentations, responses to treatments, clinical behaviors and outcomes. BC remains the most prevalent cancer type among women globally with over 2 million new cases in 2018. Major treatment strategies for BC consist of radiotherapy, surgery and chemotherapy, either separately or in combination. However, bioactive compounds present in fruits and vegetables have been demonstrated to exert multiple anti-tumoral effects, such as inhibition of cell proliferation, modulation of cell signaling pathways and gene expressions and induction of apoptosis. Accordingly, berries are gaining increasing attentions for their chemopreventive and therapeutic potential against several cancers, including BC. Their composition includes dietary fiber, organic acids, certain minerals in trace amounts, some vitamins and phytochemicals (such as, phenolic compounds). All of these components, individually or combined, are associated with their antioxidant properties and responsible for their health benefits. Therefore, the aim of this review is to discuss the recent evidence, obtained from in vitro, in vivo and human studies, on the potential roles exerted by different phenolic compounds or different phenolic extracts from berries in the prevention of $\mathrm{BC}$ progression.
\end{abstract}

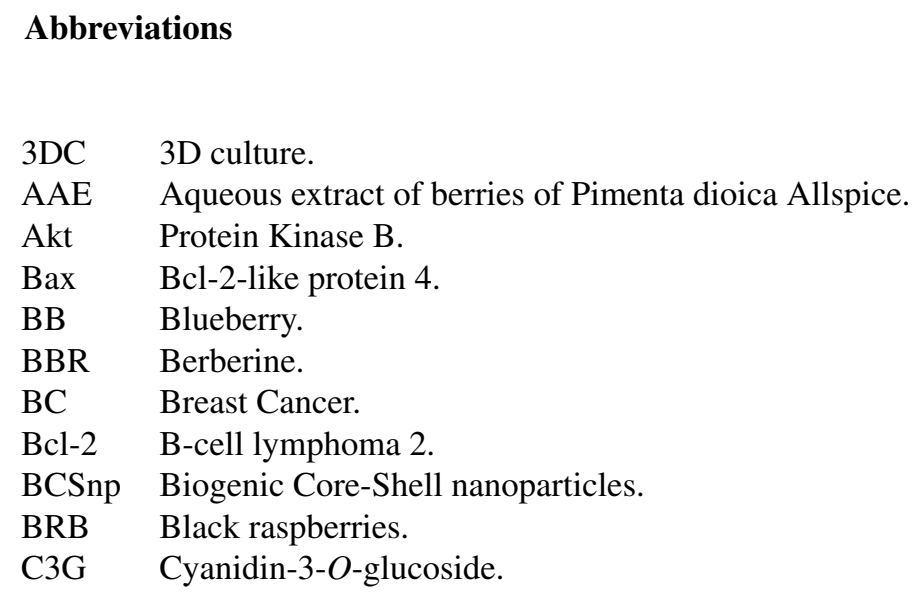

\footnotetext{
*Corresponding author: Patricia Reboredo-Rodríguez. E-mail: preboredo@uvigo.es.
} 


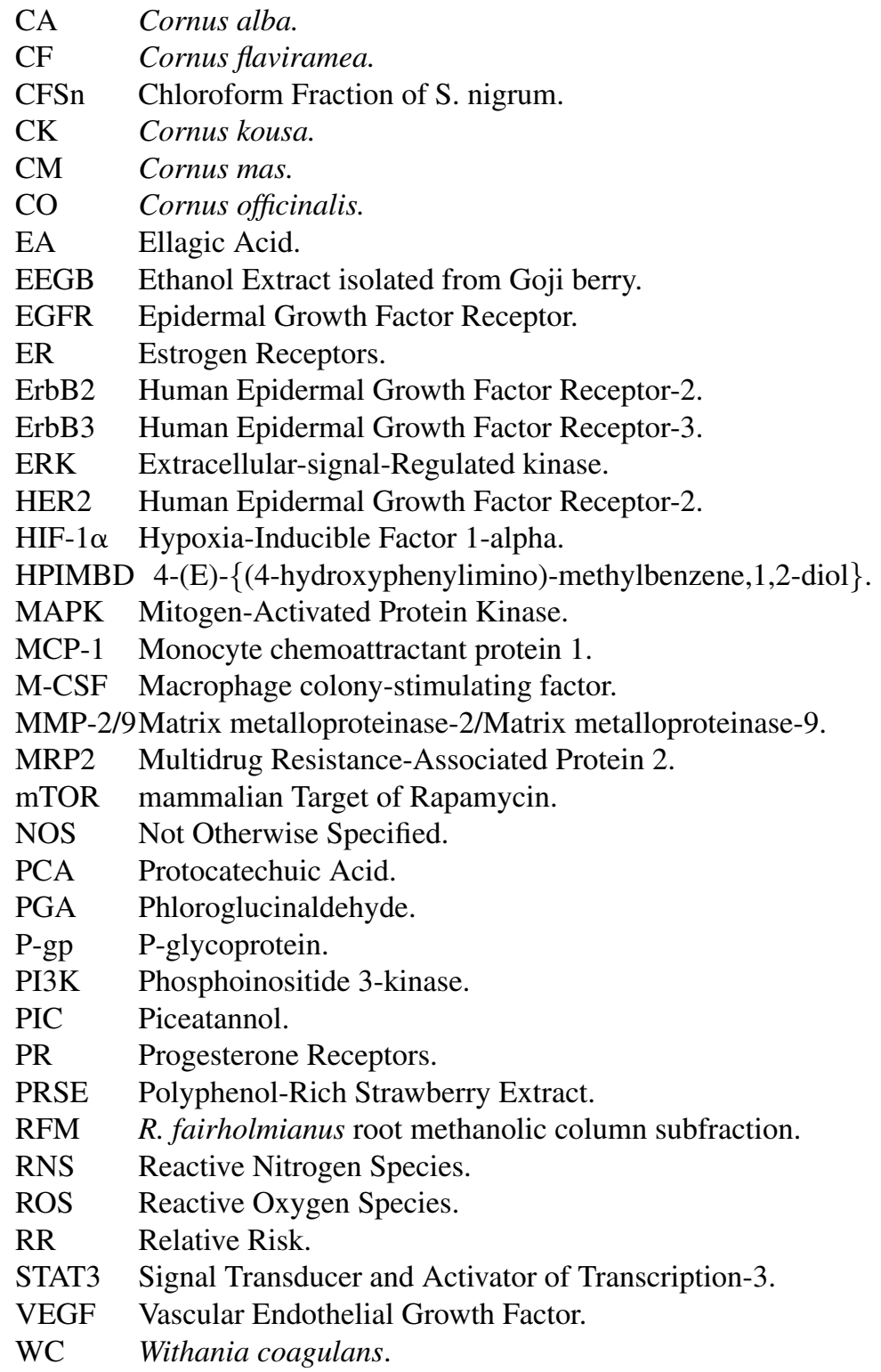

\section{Introduction}

Breast cancer (BC) remains the most prevalent cancer type among women globally with over 2 million new cases in 2018 [1]. BC encompasses a collection of different diseases characterized by different biological and pathological features, clinical presentations, responses to treatments, clinical behaviors and outcomes [2]. Its traditional classification was according to histological parameters, separating BCs into ductal, lobular, nipple, or not otherwise specified (NOS) [3]. Nowadays, molecular classification using immunohistochemistry to reflect 
the hormone-responsiveness of the tumors and other cell markers have become increasingly useful for dictating treatment and prognosis [3]. The molecular subtypes of $\mathrm{BC}$, which are based on the presence or absence of estrogen receptors (ER), progesterone receptors (PR), and human epidermal growth factor receptor-2 (HER2), include: (i) luminal A (ER+ and/or PR+; HER2-); (ii) luminal B (ER+ and/or PR+; HER2+); (iii) basal-like (ER-, PR-, and HER2-); and (iv) HER2-enriched (ER-, PR-, and HER2+) [4-6]. Tumors in a specific histological subtype do not always belong to the same molecular classification. In addition, the hormone responsiveness does not determine the molecular subtype [7].

Major treatment strategies for BC consist, either separately or in combination of, radiotherapy, surgery and chemotherapy [8]. In recent years, phytochemicals present in plant foods were used to develop novel agents to suppress the progression of cancers because they are considered to be relatively safe, as evidenced through the extensive human consumption [9]. In this sense, berries are gaining increasing attentions for their chemopreventive and therapeutic potential against several cancers [10].

The most commonly widely consumed berries in the world are cranberries (Vaccinum macrocarpon), blackberries (Rubus species), blueberries (Vaccinum corymbosum), raspberries (Rubus ideus) and strawberries (Fragaria ananassa) together with elderberries, mulberries and other less common red fruits in some particular environments [11-13]. Their chemical composition is variable depending on the cultivar and variety, growing location and environmental conditions, plant nutrition, ripeness stages, time of harvest, as well as subsequent storage conditions [14]. They contain a high amount of dietary fiber (cellulose, hemicellulose and pectin), organic acids (citric, malic, tartaric, oxalic and fumaric acids), certain minerals in trace amounts, some vitamins (ascorbic and folic acids) and phytochemicals (such as phenolic compounds) [14].

Phenolic compounds present in berries include flavonoids, such as anthocyanins (i.e., cyanidin glucosides and pelargonidin glucosides), flavonols (quercetin, kaempferol and myricetin), flavanols (catechins and epicatechin), phenolic acids (hydroxybenzoic and hydroxycinnamic acids) and hydrolysable tannins (such as ellagitannins) [15]. These components, either individually or combined, have been considered to associate with their antioxidant properties and are responsible for most of berry health benefits.

The bioavailability of phenolic compounds is generally measured by the evaluation of urine excretion [16-18]. Anthocyanins, for example, are widely reported to have low bioavailability, with the majority of studies recording peak plasma concentrations ranging from 1 to $120 \mathrm{nmol} / \mathrm{L}$ [19] and urinary recoveries $<2 \%$ of intake $[20,21]$. On the other hand, it is almost certainly that potential in vivo health effects of anthocyanins are the results of the presence of their metabolites in the circulatory system rather than the parent compounds, which are present in the ingested foods. Anyway, anthocyanins are considered to be a good candidate for preventing the development of cancers by protecting cells from the damage caused by reactive oxygen species (ROS) [22]. Furthermore, bioactive phytochemical compounds such as phenolic acid, proanthocyanidins, anthocyanin and other flavonoids offer protection against $\mathrm{BC}$ by arresting the cell cycle [23].

Health benefits associated with phytochemicals and dietary compounds intake are currently being investigated and have recently gained attention because numerous studies have delineated their potential roles in preventing, inhibiting and reversing the progression of cancers. This review aims to update and discuss the effects that different phenolic compounds or different phenolic extracts from berries on BC prevention and management. In particular, in vitro, in vivo and human studies published in the last five years were discussed.

\section{Biological activities of berries and their bioactive compounds against breast cancer}

The latest developments on the preventive and therapeutic activities of berries and their bioactive compounds from in vitro, in vivo and human studies against BC have been summarized in Fig. 1. 


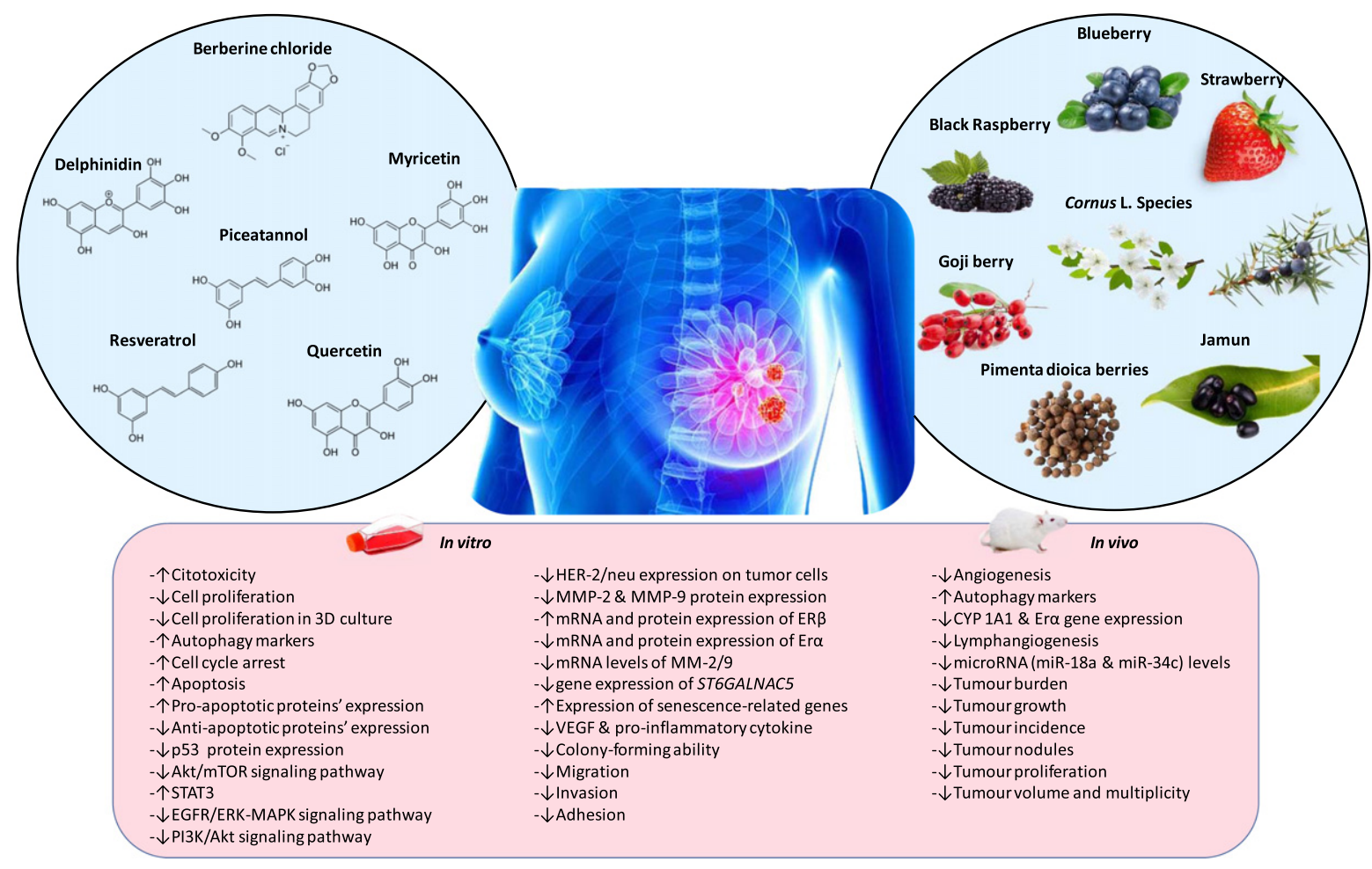

Fig. 1. Anti-tumor and anti-cancer effects of different phenolic compounds or different phenolic extract from berries.

\subsection{Isolated compounds}

Berberine, delphinidin, myricetin, piceatannol, quercetin and resveratrol together with their derivatives are among the most studied phenolic compounds during the last 5 years (Table 1).

Berberine (BBR) is a naturally occurring isoquinoline alkaloid isolated from Barberry (Berberis vulgaris L., Berberidaceae family) and many other plants used in Chinese herbal medicine [24]. Pierpaoli et al. (2013) [25] investigated the antitumor effect of BBR and of four selected BBR derivatives (NAX012, NAX013, NAX014 and NAX035) in human HER-2/neu overexpressing BC SK-BR-3 cells. The results demonstrated the greater effectiveness of NAX012 and NAX014 analogs in inducing apoptosis and cellular senescence in HER-2/neu overexpressing tumor cell lines.

Delphinidin is a major anthocyanin that constitutes a core structure same as that present in cyanidin, malvidin, pelargonidin, peonidin and petunidin [26]. Seo (2013) [27] reported that delphinidin inhibits cell growth, proliferation and induces apoptosis in MDA-MB-231 human BC cell line. Result showed that delphinidin inhibited BC cell growth in a dose dependent manner by decreasing the expression of ErbB2, ErbB3, total Akt and phosphorylated Akt. At the same time, Bcl-2 levels were dose-dependently decreased and Bax expression was significantly increased in cells treated with delphinidin.

Myricetin is a natural polyphenol which can be found in teas, wines and berries. Ci et al. (2018) [28] investigated the pharmacodynamic actions and molecular mechanisms of myricetin on BC metastasis which was unknown so far. Results showed that myricetin could significantly block invasion of MDA-MB-231 cells through suppressing the protein expression of MMP-2/9 and the expression of ST6GALNAC5, as well as lung metastasis, suggesting, therefore, that it should be considered as a potential therapeutic candidate for BC. 
Table 1

Effects of isolated compounds on in vitro and/or in vivo models of breast cancer

\begin{tabular}{|c|c|c|c|c|}
\hline Extracts/Fraction/Component & Experimental model & $\begin{array}{l}\text { Dosage and duration of } \\
\text { treatment }\end{array}$ & $\begin{array}{l}\text { Biological } \\
\text { response/involved } \\
\text { pathway }\end{array}$ & Ref. \\
\hline $\begin{array}{l}\text { Berberine chloride (BRB), NAX012, } \\
\text { NAX013, NAX014 \& NAX035. }\end{array}$ & $\begin{array}{l}\text { Human breast cancer cell line } \\
\text { SK-BR-3. }\end{array}$ & $\begin{array}{l}50 \mu \mathrm{M} \text { of BBR, NAX012 } \\
\text { or NAX014 for } 24,48 \& \\
72 \mathrm{~h} .\end{array}$ & $\begin{array}{l}-\uparrow \text { Cytotoxicity. } \\
-\uparrow \text { Apoptosis. } \\
-\uparrow \text { Expression of } \\
\text { senescence-related genes. } \\
-\downarrow \text { HER-2/neu expression } \\
\text { on tumor cells. } \\
-\downarrow \text { Phosphorylation on } \\
\text { tumor cells. }\end{array}$ & {$[25]$} \\
\hline Delphinidin & $\begin{array}{l}\text { Human breast cancer cell line } \\
\text { MDA-MB- } 231 \text {. }\end{array}$ & $5 \mu \mathrm{mol} / \mathrm{L}$ of delphinidin. & $\begin{array}{l}-\downarrow \text { Cell proliferation. } \\
-\uparrow \text { Apoptosis. }\end{array}$ & [27] \\
\hline Myricetin & $\begin{array}{l}\text { Human breast cancer brain } \\
\text { metastasis cell lines } \\
\text { (BCBM, MDAMb-231Br). } \\
\text { Female BALB/c mice } \\
\text { (six-week-old) injected with } \\
\text { mouse breast cancer cell lines } \\
\text { (4T-1). }\end{array}$ & $\begin{array}{l}\text { In vitro: } 2.5,5 \& 10 \mu \mathrm{M} \\
\text { of myricetin for } 24 \& \\
48 \mathrm{~h} \text {. } \\
\text { In vivo: Intraperitoneally } \\
\text { dosed daily ( } 25 \text { and } \\
50 \mathrm{mg} / \mathrm{kg} \text { ) starting } 48 \mathrm{~h} \\
\text { and continued until } \\
\text { sacrifice on day } 14 .\end{array}$ & $\begin{array}{l}-\downarrow \text { Invasion. } \\
-\downarrow \text { Adhesion. } \\
-\downarrow \text { MMP-2 \& MMP-9 } \\
\text { protein expression. } \\
-\downarrow \text { mRNA levels of } \\
\text { MMP-2/9. } \\
-\downarrow \text { gene expression of } \\
\text { ST6GALNAC5. } \\
-\downarrow \text { Tumour nodules in } \\
\text { vivo. }\end{array}$ & [28] \\
\hline Piceatannol & $\begin{array}{l}\text { Female BALB/c mice } \\
\text { (four-week-old) injected with } \\
\text { 4T1 murine mammary } \\
\text { carcinoma cell line. }\end{array}$ & $\begin{array}{l}10-\text { or } 20-\mathrm{mg} / \mathrm{kg} \text { body } \\
\text { weight } / \text { day of piceatannol } \\
\text { was orally administered } \\
\text { daily for } 30 \text { days, starting } \\
1 \text { day after the } \\
\text { implantation of tumor } \\
\text { cells. }\end{array}$ & $\begin{array}{l}-\downarrow \text { Tumor proliferation. } \\
-\downarrow \text { Angiogenesis. } \\
-\downarrow \text { Lymphangiogenesis. }\end{array}$ & [9] \\
\hline Quercetin & $\begin{array}{l}\text { Human breast cancer cell line } \\
\text { MCF- } 7 \text {. }\end{array}$ & - & - & [30] \\
\hline Resveratrol & $\begin{array}{l}\text { Human breast cancer cells } \\
\text { T-47D. }\end{array}$ & $\begin{array}{l}0-100 \mu \mathrm{M} \text { of resveratrol } \\
\text { for } 24 \mathrm{~h} \& 6 \text { days. }\end{array}$ & $\begin{array}{l}-\downarrow \text { Cell proliferation. } \\
-\downarrow \text { p53 protein expression. } \\
-\downarrow E R \alpha \text { protein } \\
\text { expression. }\end{array}$ & [32] \\
\hline
\end{tabular}


Table 1

(Continued)

\begin{tabular}{|c|c|c|c|c|}
\hline Extracts/Fraction/Component & Experimental model & $\begin{array}{l}\text { Dosage and duration of } \\
\text { treatment }\end{array}$ & $\begin{array}{l}\text { Biological } \\
\text { response/involved } \\
\text { pathway }\end{array}$ & Ref. \\
\hline Resveratrol analog, HPIMBD & $\begin{array}{l}\text { Breast cancer cell lines MCF-7, } \\
\text { T47D \& MDA-MB- } 231 .\end{array}$ & $\begin{array}{l}50 \mu \mathrm{M} \text { of resveratrol and } \\
25,50 \& 100 \mu \mathrm{M} \text { of } \\
\text { HPIMBD for } 12,24,48 \& \\
72 \mathrm{~h} .\end{array}$ & $\begin{array}{l}-\uparrow \mathrm{mRNA} \text { and protein } \\
\text { expression levels of ER } \beta . \\
-\downarrow \mathrm{mRNA} \text { and protein } \\
\text { expression levels of ER } \alpha .\end{array}$ & [34] \\
\hline Resveratrol analogue, HS-1793 & $\begin{array}{l}\text { Human breast cancer cell lines } \\
\text { MCF-7 (wild-type p53) and } \\
\text { MDA-MB-231 (mutant type } \\
\text { p53). }\end{array}$ & $\begin{array}{l}12.5,25 \& 50 \mu \mathrm{M} \text { of } \\
\text { resveratrol and } 3.0,6.25, \\
12.5,25 \& 50 \mu \mathrm{M} \text { of } \\
\text { HS-1793 for } 24 \mathrm{~h} .\end{array}$ & $\begin{array}{l}-\downarrow \text { Cell growth. } \\
-\uparrow \text { Apoptosis. } \\
-\uparrow \text { Cell cycle arrest. }\end{array}$ & [31] \\
\hline Resveratrol derivative, UHA6052 & $\begin{array}{l}\text { Human breast cancer cell line } \\
\text { MCF- } 7 \text {. }\end{array}$ & $\begin{array}{l}0.625,1.25,2.5,5,10 \& \\
20 \mu \mathrm{M} \text { of UHA6052 for } \\
2,4 \& 7 \text { days. }\end{array}$ & $\begin{array}{l}-\downarrow \text { Cell proliferation in } 3 \mathrm{D} \\
\text { culture. }\end{array}$ & [35] \\
\hline
\end{tabular}

Piceatannol (PIC, trans-3,4,3',5'-tetrahydroxystilbene) is a natural polyphenolic stilbene present in rhubarb, berries, peanuts, sugar cane, red wine and the skins of grapes [29]. Song et al. (2015) [9] reported that PIC treatment reduced tumor growth. In tumor tissues, PIC treatment decreased levels of phosphorylation of $-\mathrm{NF} \kappa \mathrm{B}$ p 65 and Signal Transducer and Activator of Transcription-3 (STAT3) together with levels of HIF-1 $\alpha$ and multiple proteins involved in regulation of cell cycle progression, angiogenesis, lymphangiogenesis and macrophage infiltration. Moreover, PIC significantly increased apoptotic cells, which was related to increased expression of both Bax and cleaved caspase-3, and decreased Bcl-2 expression. Finally, PIC reduced the number and volume of metastatic pulmonary tumor nodules and expression of MMP-9 in both lung and mammary tumors. It also reduced tissue levels of cytokines/chemokines, including M-CSF and MCP-1.

Quercetin (3,5,7,3',4'-pentahydroxyflavone) is a natural bio-flavonoid that can be found in fruits, vegetables, seeds, berries and tea. In order to increase the hydrophilicity and drug delivery capability, Rezaei-Sadabady et al. (2016) [30] encapsulated quercetin into liposomes and studied the in vitro effects of this compound on proliferation using MCF-7 human breast carcinoma cells. The anti-proliferative activity of liposomal quercetin was better than that of free quercetin (at equimolar concentrations), suggesting that liposomal quercetin can significantly improve the solubility and bioavailability of quercetin and has the potential to treat breast tumor.

Recent epidemiologic studies have suggested a protective role of phytoestrogens in prevention of breast and other cancers. Resveratrol, a naturally occurring phytoestrogen found notably in red grapes, berries and peanuts [31], has been shown to possess potent anti-cancer properties. Effects on cell proliferation and regulation of both $\mathrm{p} 53$ and $\mathrm{ER} \alpha$ by resveratrol may lead to further understanding of the relationship between tumor suppressor proteins and steroid receptors in T-47D human BC cells [32]. Resveratrol caused a decrease in the levels of protein expression of $\mathrm{p} 53$ and $\mathrm{ER} \alpha$ as compared to the control [32]. However, this molecule was proven to have poor bioavailability and, therefore, not relevant to the effects observed in humans [33]. In order to improve the efficacy of resveratrol, several studies focused on synthesizing resveratrol analogues or derivatives to enhance its poor bioavailability. Ronghe et al. (2014) [34] have recently shown that one of the synthesized analogs, 4-(E)-\{(4hydroxyphenylimino)-methylbenzene,1,2-diol $\}$ (HPIMBD), has better anti-cancer properties than resveratrol. This novel azaresveratrol analog may inhibit the proliferation of BC cells by differentially modulating the expressions of ER $\alpha$ and ER $\beta$. Kim et al. (2014) [31] studied the effects of a synthetic analogue of resveratrol, HS-1793, on the proliferation and apoptosis using MCF-7 (wild-type p53) and MDA-MB-231 (mutant p53) human BC cells. HS-1793 inhibited cell growth and induced apoptosis in a concentration-dependent manner. 
Moreover, flow cytometric analysis revealed that HS-1793 induced G2/M arrest in the cell cycle progression in both types of cells. Of note, HS-1793 induced p53/p2 $1^{\mathrm{WAF} 1 / \mathrm{CIP} 1}$-dependent apoptosis in MCF-7 cells, whereas it exhibited p53-independent apoptosis in MDA-MB-231 cells. Lastly, a novel resveratrol derivative (UHA6052) -which is conjugated with caffeic acid- has been examined by Okamoto et al. (2018) [35]. The UHA6052 treatment significantly inhibited MCF-7 cell proliferation in 3D culture 3DC. This effect was stronger than the parent compound, resveratrol, and equally effective as 5-fluorouracil, a conventional cancer therapy drug [36].

\subsection{Berries and their extracts}

Over the years, berries have received much attention from their beneficial health properties [37, 38]; different in vitro and in vivo studies have been performed in the last five years to deeply investigate their roles in BC prevention and treatment (Table 2).

Black raspberries (BRB) contain multiple compounds with chemopreventive potential including vitamins A, C and $\mathrm{E}$, selenium and calcium, numerous complex and simple polyphenols (anthocyanins, ellagitannins, quercetin, ferulic and coumaric acids), various carotenoids and phytohormones such as $\beta$-sitosterol. Preclinical studies have shown that freeze-dried BRB powder inhibits the development of oral, esophageal, colon and breast tumors in animals [39].

Blueberry (BB) is among the few fruits that contain five major anthocyanidins (cyanidin, delphinidin, malvidin, peonidin and petunidin) [40]. Anthocyanins activate phase II enzymes and induce apoptosis as well as exert antiproliferative, anti-inflammatory and antiangiogenesis properties [41]. Jeyabalan et al (2014) [10] reported both chemopreventive and therapeutic potentials of highbush BB powder, together with the possible mechanisms by which BB blend may inhibit mammary tumorigenesis. Results showed that tumor volume and multiplicity were significantly reduced. The effect on mammary tumorigenesis was largely due to down-regulation of CYP $1 \mathrm{~A} 1$, ER- $\alpha$ gene expression and also favorable modulation of microRNA (miR-18a and miR-34c) levels. These data suggest that BB is effective in inhibiting estrogen (E2)-mediated mammary tumorigenesis in both preventive and therapeutic modes.

Cornaceae plants are known for their edible berries and their leaves are used as tea [42]. Aqueous leaf extracts from Cornus mas (CM), C. alba (CA), C. flaviramea (CF), C. kousa (CK) and C. officinalis (CO) were tested for their antiproliferative activity in MCF-7 human BC cells. The tested extracts induced time dependent decreases in cell survival being $\mathrm{CA}, \mathrm{CO}$ and $\mathrm{CM}$ the most effective. The effectiveness was related to the tannins and total polyphenols contents [42].

There are only a few scientifically robust mechanistic studies with Lycium barbarum fruits, also known as Goji berry red fruit, that have addressed preventive or therapeutic potential of BC. Wawruszak et al. (2016) [43] reported the anticancer activity of ethanol extract obtained from Goji berry (EEGB) on T47D human BC cell line. EEGB inhibited the proliferation of BC cells in time-, and dose-dependent manner together with the lack of cytotoxicity to normal human skin fibroblasts. Western blot analysis demonstrated an increase in proapoptotic and a decrease in anti-apoptotic protein expression in cells treated with EEGB. Cumaoğlu et al. (2018) [44] investigated the antiproliferative effects of both Lycium barbarum fruit (Goji berry red fruit) and Lycium ruthenicum (Goji berry black fruit) extracts against triple-negative MDA-MB-231 cells and explored the possible mechanisms of their anticancer effects. Results showed that treatment with Goji berry fruit extracts inhibited the expression of anti-apoptotic Bcl-2, but enhanced pro-apoptotic Bax expression at transcriptional levels and induced cancer cell apoptosis by the activation of pro-apoptotic caspase- 9 and caspase 3. Goji berry fruit extracts caused the mentioned death of MDA-MB-231 BC cells by inhibiting EGFR/ERK-mitogen activated protein kinases (MAPK) and PI3K/Akt signaling pathways.

The predominant anthocyanin in haskap berries (Lonicera caerulea L.) is cyanidin-3-O-glucoside (C3G) which possesses antioxidant and many other biological activities [45]. The impact of temperature and $\mathrm{pH}$ on the degradation of the $\mathrm{C} 3 \mathrm{G}$-rich haskap fraction has been investigated together with the effect of the thermal degradation of the products. The $\mathrm{C} 3 \mathrm{G}$ stability in these fractions was studied under elevated temperatures $\left(70^{\circ} \mathrm{C}\right.$ 
Table 2

Effects of berries and their extracts on in vitro and/or in vivo models of breast cancer

\begin{tabular}{|c|c|c|c|c|}
\hline $\begin{array}{l}\text { Extracts/Fraction } \\
\text { /Component }\end{array}$ & Experimental model & $\begin{array}{l}\text { Dosage and duration of } \\
\text { treatment }\end{array}$ & $\begin{array}{l}\text { Biological response } \\
\text { /involved pathway }\end{array}$ & Ref. \\
\hline Blueberry & $\begin{array}{l}\text { Female ACI rats ( } 5-6 \text { weeks } \\
\text { old). }\end{array}$ & $\begin{array}{l}\text { Animals received } 5 \% \text { blueberry } \\
\text { diet, either } 2 \text { weeks prior to or } 12 \\
\text { weeks after } E_{2} \text { treatment. }\end{array}$ & $\begin{array}{l}-\downarrow \text { Tumor volume and } \\
\text { multiplicity. } \\
-\downarrow \text { CYP } 1 \text { A } 1 \text { and ER- } \alpha \text { gene } \\
\text { expression. } \\
-\downarrow \text { microRNA (miR-18a and } \\
\text { miR-34c) levels. }\end{array}$ & {$[10]$} \\
\hline Cornus L. Species & $\begin{array}{l}\text { Human breast cancer cell line } \\
\text { MCF- } 7 \text {. }\end{array}$ & $\begin{array}{l}50-750 \mu \mathrm{g} / \mathrm{mL} \text { of aqueous leaf } \\
\text { extracts from Cornus mas }(\mathrm{CM}) \text {, } \\
\text { C. alba }(\mathrm{CA}), \text { C. flaviramea }(\mathrm{CF}) \text {, } \\
\text { C. kousa }(\mathrm{CK}) \& \text { C. officinalis } \\
\text { (CO) for } 24,48 \& 72 \mathrm{~h} .\end{array}$ & $-\downarrow$ Cell proliferation. & [42] \\
\hline Goji berry & $\begin{array}{l}\text { Human breast carcinoma cell } \\
\text { line T47D. }\end{array}$ & $\begin{array}{l}0.05,0.1,0.5,1 \& 2 \mathrm{mg} / \mathrm{mL} \text { of } \\
\text { ethanol extract isolated from Goji } \\
\text { berry (EEGB) for } 24 \& 48 \mathrm{~h} .\end{array}$ & $\begin{array}{l}-\downarrow \text { Cell proliferation. } \\
\text { - } \uparrow \text { Pro-apoptotic proteins’ } \\
\text { expression. } \\
-\downarrow \text { Anti-apoptotic proteins’ } \\
\text { expression. }\end{array}$ & [43] \\
\hline Goji berry & $\begin{array}{l}\text { Human breast cancer cell line } \\
\text { MDA-MB- } 231 \text {. }\end{array}$ & $\begin{array}{l}\text { Lycium barbarum fruit (Goji } \\
\text { berry red fruit) and Lycium } \\
\text { ruthenicum (Goji berry black } \\
\text { fruit) extracts. }\end{array}$ & $\begin{array}{l}-\uparrow \text { Apoptosis ( } \uparrow \text { caspase-9 \& } \\
\text { caspase } 3 \text { ). } \\
\text { - } \downarrow \text { EGFR/ERK-MAPK } \\
\text { signaling pathway. } \\
-\downarrow \text { PI3K/Akt signaling } \\
\text { pathway. }\end{array}$ & [44] \\
\hline Haskap Berry & $\begin{array}{l}\text { Human breast cancer cell line } \\
\text { MDA-MB- } 231 \text {. }\end{array}$ & $\begin{array}{l}\text { PE: C3G-rich fraction; HPE2: PE } \\
\text { subjected to } 90^{\circ} \mathrm{C} \text { for } 2 \mathrm{~h} \text {; HPE8: } \\
\text { PE subjected to } 90^{\circ} \mathrm{C} \text { for } 8 \mathrm{~h} \text {; CE: } \\
\text { crude extract for } 24 \& 48 \mathrm{~h} \text {. }\end{array}$ & $-\sim$ Cell proliferation. & {$[45]$} \\
\hline Jamun & $\begin{array}{l}\text { Female ACI rats ( } 5-6 \text { weeks } \\
\text { old). }\end{array}$ & $\begin{array}{l}\text { AIN-93M diet or diet } \\
\text { supplemented with }(5 \%, \mathrm{w} / \mathrm{w}) \\
\text { Jamun powder for } 26 \text { weeks. }\end{array}$ & $\begin{array}{l}-\downarrow \text { Tumor incidence. } \\
-\downarrow \text { Tumor burden. } \\
-\downarrow \text { Tumor multiplicity. } \\
-\downarrow \text { Estrogen-associated growth } \\
\text { of pituitary prolactinomas, } \\
\text { circulating prolactin and } \\
\text { estradiol levels. } \\
\text {-Offset estrogen-associated } \\
\text { increases in mammary } \\
\text { cell-proliferation, ER- } \alpha \text { and } \\
\text { cyclinD1. }\end{array}$ & {$[48]$} \\
\hline
\end{tabular}


Table 2

(Continued)

\begin{tabular}{|c|c|c|c|c|}
\hline $\begin{array}{l}\text { Extracts/Fraction } \\
\text { /Component }\end{array}$ & Experimental model & $\begin{array}{l}\text { Dosage and duration of } \\
\text { treatment }\end{array}$ & $\begin{array}{l}\text { Biological response } \\
\text { /involved pathway }\end{array}$ & Ref. \\
\hline $\begin{array}{l}\text { Juniperus oxycedrus ssp. } \\
\text { oxycedrus berries }\end{array}$ & $\begin{array}{l}\text { Human breast cancer cell line } \\
\text { MCF- } 7 \text {. }\end{array}$ & $\begin{array}{l}50,80,200,300 \& 400 \mu \mathrm{g} \text { of } J . \\
\text { oxycedrus } n \text {-butanol extract for } \\
24 \mathrm{~h} ; 5,10,20,30,40 \& 50 \mu \mathrm{M} \\
\text { of compound } 2 \text { for } 24 \mathrm{~h} .\end{array}$ & $\begin{array}{l}\text {-Modulation of overexpressed } \\
\text { (miR-182 and miR-375) or } \\
\text { underexpressed (miR-127 } \\
\text { and miR-206). } \\
-\downarrow \text { Cell viability by } n \text {-butanol } \\
\text { extracts. } \\
-\downarrow \text { Cell viability by compound } \\
2 \text { (30 } \mu \mathrm{M} \text { ). } \\
-\sim \text { Apoptosis by compound } 2 \text {. } \\
-\uparrow \text { Cell cycle arrest at G0/G1 } \\
\text { phase by compound } 2 \text {. } \\
-\downarrow \text { VEGF \& pro-inflammatory } \\
\text { cytokine (IL-8, IL-12, IP-10, } \\
\text { RANTES \& MCP-1) levels. }\end{array}$ & {$[50]$} \\
\hline $\begin{array}{l}\text { Pimenta dioica berries } \\
\text { (Allspice) }\end{array}$ & $\begin{array}{l}\text { Human breast cancer cell lines } \\
\text { MCF7, MDA-MB231, SKBr3, } \\
\text { BT474 \& T47D. } \\
\text { Athymic female mice (6-8 } \\
\text { weeks old) injected with } \\
\text { MB-231 cells. }\end{array}$ & $\begin{array}{l}50-150 \mu \mathrm{g} / \mathrm{mL} \text { of aqueous extract } \\
\text { of Allspice (AAE) for } 24-72 \mathrm{~h} \text {. } \\
\text { Mice were gavaged daily with a } \\
\text { solution of AAE in water } \\
(150 \mathrm{mg} / \mathrm{kg} \text { ) for } 8 \text { weeks (except } \\
\text { in group } 5 \text { where were euthanized } \\
\text { at the end of } 9 \text { weeks because, } 4 \\
\text { out of } 6 \text { mice }(76 \%) \text { did not have } \\
\text { palpable tumor). }\end{array}$ & $\begin{array}{l}-\downarrow \text { Replication potential } \\
\text { (colony-forming ability). } \\
\text { - } \uparrow \text { Autophagy markers LC3B } \\
\text { and LC3B-positive puncta. } \\
\text { (Silencing the expression of } \\
\text { autophagy related genes } \\
\text { (ATGs) prevented } \\
\text { AAE-induced cell death). } \\
-\downarrow \text { Akt/mTOR signaling } \\
\text { pathway. } \\
-\downarrow \text { Tumor growth. } \\
-\uparrow \text { Autophagic tumor cell } \\
\text { death in vivo. }\end{array}$ & {$[51]$} \\
\hline $\begin{array}{l}\text { Poha Berry (Physalis } \\
\text { peruviana) }\end{array}$ & $\begin{array}{l}\text { Human breast cancer cell line } \\
\text { MDA-MB- } 231 \text {. }\end{array}$ & - & $\begin{array}{l}-\downarrow \text { Cell growth. } \\
-\uparrow \text { STAT3. }\end{array}$ & {$[52]$} \\
\hline \multirow[t]{2}{*}{ Rubus fairholmianus } & $\begin{array}{l}\text { Human breast cancer cell line } \\
\text { MCF- } 7 \text {. }\end{array}$ & $\begin{array}{l}5,10 \& 20 \mu \mathrm{g} / \mathrm{mL} \text { of RFM for } \\
24 \mathrm{~h} .\end{array}$ & $\begin{array}{l}-\uparrow \text { Cell damage. } \\
-\downarrow \text { Cell number. } \\
-\downarrow \text { Cell viability. }\end{array}$ & {$[53]$} \\
\hline & $\begin{array}{l}\text { Dalton's Lymphoma Ascites } \\
\text { (DLA) cells were injected } \\
\text { subcutaneously of Swiss albino } \\
\text { mice for solid tumor growth. }\end{array}$ & $\begin{array}{l}25,50 \& 100 \mathrm{mg} / \mathrm{kg} \text { b.wt of RFM } \\
\text { for } 40 \text { days. }\end{array}$ & $\begin{array}{l}-\uparrow \text { Apoptosis. } \\
-\downarrow \text { Tumor volume. } \\
-\downarrow \text { Tumor weight. } \\
-\uparrow \text { Life span. }\end{array}$ & \\
\hline
\end{tabular}


Table 2

(Continued)

\begin{tabular}{|c|c|c|c|c|}
\hline & Ehrlich Ascites Carcinoma & & & \\
\hline & (EAC) cells were injected & & & \\
\hline & intraperitoneally of Male Swiss & & & \\
\hline & albino mice for ascites tumor & & & \\
\hline & growth. & & & \\
\hline \multirow[t]{2}{*}{ Solanum nigrum L. } & Human breast cancer cell lines & Chloroform fraction of Solanum & $-\downarrow$ Cell proliferation. & {$[55]$} \\
\hline & MDA-MB-231 \& MCF-7. & nigrum L. berries. & $-\uparrow$ Apoptosis. & \\
\hline \multirow[t]{10}{*}{ Strawberry } & Murine breast cancer cell line & In vitro: $0.5,1,2.5 \& 5 \mathrm{mg} / \mathrm{mL}$ of & $-\downarrow$ Cell viability. & {$[56]$} \\
\hline & A17. & polyphenol-rich strawberry & $-\uparrow$ Cell cycle arrest. & \\
\hline & & extract (PRSE) from 'Alba' & $-\uparrow$ Hypodiploid cells. & \\
\hline & & variety for $48 \mathrm{~h}$. & $-\downarrow$ Migration. & \\
\hline & Old female FVB/N mice (4 & In vivo: $15 \%$ strawberry & - Modulation of genes & \\
\hline & weeks old) injected with A17 & extract-enriched food for 13 & expression involved in & \\
\hline & cells. & weeks. & migration, adhesion and & \\
\hline & & & invasion processes. & \\
\hline & & & $-\downarrow$ Tumor weight. & \\
\hline & & & $-\downarrow$ Tumor volume. & \\
\hline \multirow[t]{4}{*}{ Strawberry } & N202/1A (high levels of & Methanolic extract from & $-\downarrow$ Cell proliferation after 48 & [57] \\
\hline & HER2/neu oncogene) \& & strawberries of the Alba cultivar & $\& 72 \mathrm{~h}$. & \\
\hline & N202/1E (low levels of & for $24,48 \& 72 \mathrm{~h}$ & & \\
\hline & HER2/neu oncogene). & & & \\
\hline \multirow[t]{3}{*}{ Withania coagulans } & Human breast cancer cell line & $20-200 \mathrm{mg} / \mathrm{mL}$ of methanolic & $-\downarrow$ Cell viability. & {$[58]$} \\
\hline & MDA-MB-231. & extract of dried fruits (berries) of & -个Apoptosis. & \\
\hline & & WC for $48 \mathrm{~h}$. & & \\
\hline
\end{tabular}

and $\left.90^{\circ} \mathrm{C}\right)$ at three different $\mathrm{pH}$ values $(2.5,4$, and 7$)$ by monitoring the concentration of $\mathrm{C} 3 \mathrm{G}$ and its major degradation products, protocatechuic acid (PCA) and phloroglucinaldehyde (PGA), using liquid chromatography mass spectrometry. PGA but not PCA exhibited cytotoxic effects against MDA-MB-231 cells. The results suggest that thermal food processing of haskap could influence its biological properties due to the degradation of C3G.

Syzygium Cumini L., commonly known as 'jamun' in India and other Asian countries, is a popularly consumed berry and is used in treating certain ailments such as diabetes mellitus [46]. Jamun pulp contains anthocyanins including glycosides of delphinidin, malvidin, cyanidin, petunidin and peonidin and a significant amount of ellagic acid (EA). Perhaps, this is the only berry that contains these five different anthocyanidins and EA [47]. The potential of jamun against $17 \beta$-estrogen-mediated $\mathrm{BC}$ and the role of miRNAs and other targets in suppressing BC were reported by Aqil et al. (2016) [48]. The results showed that jamun significantly offset estrogen-mediated alterations in mammary cell-proliferation, ER- $\alpha$, cyclin D1 and candidate miRNAs. The modulation of these biomarkers correlated with a reduction in mammary carcinogenicity.

Phytochemical studies carried out using Juniperus taxa demonstrated the presence of a wide array of secondary metabolites with a variety of pharmacological effects [49]. De Marino et al. (2014) [50] reported the effects of crude $n$-butanol extract and its pure compounds 2, 3, 4 and 5 on three human cancer cell lines being MCF-7 one of them. The experiments showed that the compound 2 had effect on MCF-7 viability, exerted no significant increase of apoptosis and promoted the cell cycle arrest at G0/G1 phase when compared to untreated cells. Finally, compound 2 decreased Vascular Endothelial Growth Factor (VEGF) levels and other five pro-inflammatory cytokines suggesting its potential anti-inflammatory effect. 
Zhang et al. (2015) [51] reported that an aqueous extract of berries of Pimenta dioica Allspice (AAE) was tested against human $\mathrm{BC}$ in vitro and in vivo. In vitro studies showed that $\mathrm{AAE}$ reduced the viability and clonogenic growth of several types of $\mathrm{BC}$ cells with limited toxicity to non-tumorigenic, quiescent cells. AAE induced cytotoxicity in BC cells was inconsistent with apoptosis, but was associated with increased levels of autophagy markers LC3B and LC3B-positive puncta. Further, AAE caused inhibition of Akt/mTOR signaling and showed enhanced cytotoxicity when combined with rapamycin, a chemotherapy drug and an inhibitor of mTOR signaling. With respect to in vivo studies, oral administration of AAE to athymic mice implanted with MDA-MB-231 tumors inhibited tumor growth slightly but not significantly when mice were gavaged post-tumor implant. However, tumor growth showed a significant delay in tumor palpability and growth rate when mice were pre-dosed with AAE for two weeks before tumor implant. Analysis of tumor tissues showed increased levels of LC3B in AAE-treated tumors, indicating elevated autophagic tumor cell death in vivo in AAE-treated mice.

Poha Berry (Physalis peruviana L.) originated in tropical South America. It has become naturalized and is found in the Island of Hawai' $\mathrm{i}$. The edible fruits are commonly known as cape gooseberry or poha in Hawai' $\mathrm{i}$. Chang et al. (2016) [52] reported three new withanolides, physaperuvin G (1), physaperuvins I-J (2-3), along with four known withanolides, namely $4 \beta$-hydroxywithanolide E (4), withaperuvin C (5), physalactone (6), and coagulin (7) were isolated from the aerial parts of $P$. peruviana. In addition, two known compounds phyperunolide F (8) and withanolide $S(9)$ were isolated and identified from the poha berry fruits. Poha isolated compounds were evaluated for their growth inhibitory effects on MDA-MB-231 BC cells that harbor aberrantly-activated STAT3 compared to normal NIH-3T3 mouse fibroblasts [52].

Rubus fairholmianus is an unexplored berry in folkloric medicine. George et al. (2017) [53] investigated the importance of $R$. fairholmianus in pharmaceutical industry for the development of cost-effective cancer therapeutic drugs using in vitro and in vivo analysis. Chemical characterization, antioxidant, antiproliferative and proapoptotic properties of $R$. fairholmianus root methanolic column subfraction (RFM) were investigated. The solid and ascites tumors in mice were reduced significantly upon $100 \mathrm{mg} / \mathrm{kg}$ RFM treatment by reducing the tumor volume, tumor weight and prolonging life span. In vitro studies demonstrated that the morphological features of RFM treated MCF-7 cells showed cell damage and decreased cell numbers. Treated cells had a substantial decrease in cellular ATP proliferation, increase in LDH cytotoxicity, increase in apoptotic cell population and decrease in viable cell population. Increased caspase 3/7 activity and cytochrome c release were also observed in treated cells.

Phenolics, antioxidant and antiproliferative properties of Sea buckthorn berries were evaluated using a simulated in vitro digestion system and results were compared with a chemical extraction method [54]. Digested samples were subjected to antiproliferation evaluation against human liver, breast and colon cancer cells. Results revealed that after enzymatic digestion the phenolic compounds were quite different from the chemical extraction (more flavonoid aglycones were released, whereas less total phenolics, phenolic acids and flavonoid glycosides were detected). Although the extracellular antioxidant activity of the digested samples was lower than that of extracts, the cellular antioxidant activity and antiproliferative effects of berries were significantly enhanced by digestion. This was attributed to the higher flavonoid aglycone content and it could be verified by testing individual active compounds. The digested samples showed an almost 5-fold increase in cellular accumulative amount of isorhamnetin than pure isorhamnetin, which was attributed to the significant down regulation of the mRNA expression of efflux transporters Multidrug Resistance-Associated Protein 2 (MRP2) and P-glycoprotein (P-gp).

Solanum nigrum is a traditional Indian plant acclaimed for its medicinal properties since antiquity. Among all plant parts, fruit berries have shown to be the most pharmacologically active part. Khan et al. (2016) [55] characterized the bioactive principles of chloroform fraction of S. nigrum (CFSn) fruit berries using Gas Chromatography-Mass Spectrometry analysis. 29 different compounds belonging to different chemical classes (alkaloids, flavonoids, carbohydrates, glycosides, phytosterols, proteins, phenolic compounds and saponins) were identified. Among them, two novel phenolic compounds, benzoiisovanillin and syringic acid (4-hydroxy-3, 5-dimethoxybenzoic acid) were identified, which may be responsible for its pharmacological properties. The anticancer activity against BC cell lines (MDA-MB-231 and MCF-7) was investigated. Results indicated that 
CFSn exhibited significant antiproliferative activity against both BC cell lines due to the induction of cancer cell death through apoptosis.

Over the years, numerous studies have demonstrated the anti-proliferative effect of strawberry in several types of cancer cells, including BC cells. The biological effects of a polyphenol-rich strawberry extract (PRSE), obtained from the "Alba" variety was tested in highly aggressive and invasive basal-like BC cell line A17. Results showed that PRSE was able to decrease the cellular viability in time- and dose-dependent manner. Sub-lethal doses of PRSE induced the accumulation of cells in G1 phase of the cell cycle and inhibited cellular mobility. Gene expression analysis revealed the modulation of 12 genes playing different roles in the cellular migration, adhesion and invasion processes. Moreover, in vivo experiments showed the growth inhibition of A17 cells orthotopically transplanted in mouse mammary glands and fed PRSE [56]. A methanolic extract from strawberries of the "Alba" cultivar was also used to treat other two different BC cell lines, N202/1A (high levels of HER2/neu oncogene) and N202/1E (low levels of HER2/neu oncogene) for 24, 48 and $72 \mathrm{~h}$. Results demonstrated a higher inhibition of cell proliferation after 48 and $72 \mathrm{~h}$ of treatment [57]. Therefore, these evidences support future in vivo investigations.

The genus Withania (Family: Solanaceae) holds an important position in Ayurveda, the Indian traditional system of medicine. Withania somnifera Dunal and Withania coagulans Dunal have been documented in folklore as panaceas for various ailments since time immemorial. W. coagulans (WC), commonly called Indian cheese maker, is used for fermenting milk for cheese production in various parts of India. Ahmad et al. (2017) [58] reported that methanolic extract of WC possessed apoptotic activity against MDA-MB-231 human BC cells in vitro although it was lower in comparison to W. somnifera and warrants further investigation.

\subsection{Synthesized plant-based nanoparticles or commercial extracts}

Synthesized plant-based nanoparticles or commercial plant extracts have been tested for their possible chemotherapeutic/therapeutic properties against BC (Table 3). Biogenic Ag@Pd core-shell nanoparticles were greenly synthesized using two plant extracts with the focus to develop compounds that have enhanced anticancer/bactericidal functions [59]. A significant inhibition of cancer cell growth of MCF 7 BC cell line when it is compared to Wish normal cells. Doxorubicin was assessed as well. The findings showed that Ag@Pd was cytotoxic against MCF7 human BC cells. Therefore, the obtained biogenic core-shell nanoparticles (BCSnp) were proposed for cancer therapy with improved efficiency applying the nanomedicine approach. Tailorable properties can be obtained by tuning the individual structures.

Aronox ${ }^{\circledR}$ is a rich source of phytochemicals that are responsible for the multifunctional biological actions of this extracts [60]. Dysregulation of ROS/reactive nitrogen specie (RNS) metabolism in cancer patients has been confirmed by investigations of several oxidative/nitrative stress markers in cancer cells, plasma and various blood cells. In 2013, Kędzierska et al. (2013) [60] assessed the effects of surgery and chemotherapy (combination of doxorubicin and cyclophosphamide) on oxidative/nitrative stress in plasma from BC patients. In vitro experiments were performed in the plasma from these $\mathrm{BC}$ patients treated with commercial extract of Aronia melanocarpa (black chokeberry; Aronox ${ }^{\circledR}$ ). Results demonstrated that there was an inhibitory action of $A$. melanocarpa extract on the oxidative/nitrative stress in plasma isolated from all tested patient groups, including patients after different phases of chemotherapy.

\subsection{General dietary patterns}

Two human studies have been reported during the past five years trying to link berry intake and BC risk (Table 4). Link et al. (2013) [61] evaluated dietary patterns and their relationship to BC risk in a large cohort of woman subjects. Five predominant dietary patterns were identified using principal component factor analysis: (i) a plant-based diet (high in fruits and vegetables); (ii) a high-protein, high-fat diet (high in meats, eggs, fried foods, and high-fat condiments); (iii) a high-carbohydrate diet (high in convenient foods, pasta, and bread products); (iv) an ethnic diet (high in legumes, soy-based foods, rice, and dark-green leafy vegetables); and (v) a salad 
Table 3

Effects of synthesized plant-based nanoparticles or commercial extracts on in vitro and/or in vivo models of breast cancer

\begin{tabular}{|c|c|c|c|c|}
\hline $\begin{array}{l}\text { Extracts/Fraction } \\
\text { /Component }\end{array}$ & Experimental model & $\begin{array}{l}\text { Dosage and duration of } \\
\text { treatment }\end{array}$ & $\begin{array}{l}\text { Biological } \\
\text { response/involved } \\
\text { pathway }\end{array}$ & Ref. \\
\hline $\begin{array}{l}\text { Ag@Pd Core-shell } \\
\text { nanoparticles }\end{array}$ & $\begin{array}{l}\text { Human breast cancer cell } \\
\text { line MCF- } 7 \text {. }\end{array}$ & $\begin{array}{l}0.1698,0.3396,0.6792,1.3584 \& \\
2.7168 \mu \mathrm{g} / \mathrm{ml} \text { of Almond Ag@PdBCSnp\& } \\
\text { Black Berry Ag@PdBCSnp for } 72 \mathrm{~h} .\end{array}$ & $-\downarrow$ Cell growth. & [59] \\
\hline Aronox $^{\circledR}$ & $\begin{array}{l}55 \text { healthy volunteers \& } 47 \\
\text { invasive breast cancer. }\end{array}$ & $\begin{array}{l}\text { Blood from breast cancer patients and } \\
\text { healthy volunteers was collected and } \\
\text { immediately centrifuged ( } 2000 \mathrm{~g}, 15 \mathrm{~min} \text { ) to } \\
\text { get plasma. } \\
\text { In other experiments, whole blood (from } \\
\text { breast cancer patients and healthy } \\
\text { volunteers) was also incubated for } 15 \mathrm{~min} \text { at } \\
37^{\circ} \mathrm{C} \text { with } \text { A. melanocarpa } \text { extract } \\
(50 \mu \mathrm{g} / \mathrm{mL}) \text {. }\end{array}$ & $\begin{array}{l}-\downarrow \text { Oxidative/nitrative } \\
\text { stress in plasma after } A \text {. } \\
\text { melanocarpa } \text { extract } \\
\text { treatments. }\end{array}$ & [60] \\
\hline
\end{tabular}

Table 4

General dietary patterns link berry intake with breast cancer risk in humans

\begin{tabular}{|c|c|c|c|}
\hline Population & Dosage and duration of treatment & $\begin{array}{l}\text { Biological response/involved } \\
\text { pathway }\end{array}$ & Ref. \\
\hline $\begin{array}{l}91,779 \text { women in the California } \\
\text { Teachers Study cohort were } \\
\text { analyzed (including data from } \\
4140 \text { women with a diagnosis of } \\
\text { invasive breast cancer made } \\
\text { between } 1995 \text { and 2009). }\end{array}$ & $\begin{array}{l}\text { 16-page mailed questionnaire in } \\
\text { 1995-1996. } \\
\text { Five predominant dietary patterns } \\
\text { were identified by using principal: } \\
\text { plant-based; high-protein, high-fat; } \\
\text { high-carbohydrate; ethnic; and salad } \\
\text { and wine. }\end{array}$ & $\begin{array}{l}\text { Greater consumption of a plant-based } \\
\text { dietary pattern is associated with a } \\
\text { reduced breast cancer risk, } \\
\text { particularly for ER- PR- tumors. }\end{array}$ & [61] \\
\hline $\begin{array}{l}75,929 \text { women ( } 38 \text { to } 63 \text { years } \\
\text { old at baseline). }\end{array}$ & $\begin{array}{l}\text { Dietary data were collected for up to } \\
24 \text { years (seven times during this } \\
\text { period). }\end{array}$ & $\begin{array}{l}\text { Higher intake of berries and peaches } \\
\text { was associated with lower risk of } \\
\text { ER- breast cancer among } \\
\text { post-menopausal women. }\end{array}$ & {$[62]$} \\
\hline
\end{tabular}

and wine diet (high in lettuce, fish, wine, low-fat salad dressing, and coffee and tea). The plant-based pattern was associated with a reduction in $\mathrm{BC}$ risk; risk reduction was greater for ER-PR-tumors. The salad and wine pattern was associated with an increased risk of estrogen ER+PR+ tumors; this effect was only slightly attenuated after adjustment for alcohol consumption. Fung et al. (2013) [62] examined the associations of specific fruits and vegetables with risk of ER- postmenopausal BC. Results showed that higher intake of berries and peaches was associated with lower risk of ER- BC among post-menopausal women. The multivariate relative risk (RR) for consuming every 2 servings/week for total berries was 0.82 , the RR for women who consumed at least one serving of blueberries per week was 0.69 compared with non-consumers; and the RR for consuming at least 2 servings of peaches/nectarines per week was 0.59. Interesting, the risk of ER-BC was not associated with intakes of other specific fruits or vegetables. These results were considered exploratory and needed to be confirmed in further studies [62]. 


\section{Conclusions}

The present work aimed to summarize the effects of different phenolic compounds or different phenolic extracts from berries in studies published during the past five years. Several in vitro and in vivo studies have demonstrated that the compounds present in berries play key roles in cancer prevention by inactivating carcinogens, decreasing cell proliferation, inducing cell cycle arrest and apoptosis, and inhibiting angiogenesis in many types of tumors.

Phenolic extracts from "newly-red fruits" specific from particular environments (such as, Goji berry and Jasmun) showed preventive and/or therapeutic potential for breast cancer. The possible mechanisms of their anticancer effects have been widely addressed.

Human studies addressed the importance of a plant-based pattern rich in fruits and vegetables and breast cancer risk reduction. Higher intake of berries and peaches was associated with lower risk of estrogen receptorbreast cancer among post-menopausal women. Anyway, future human studies are warranted to investigate the therapeutic potential of berries in humans.

\section{Acknowledgments}

Patricia Reboredo-Rodríguez acknowledges Xunta de Galicia her post-doctoral contract.

\section{References}

[1] Breast cancer statistics. Available online: https://www.wcrf.org/dietandcancer/cancer-trends/breast-cancer-statistics (accessed on 8 Novembre 2018).

[2] Dieci MV, Orvieto E, Dominici M, Conte P, Guarneri V. Rare breast cancer subtypes: Histological, molecular, and clinical peculiarities. Oncologist. 2014;19(8):805-13. doi: 10.1634/theoncologist.2014-0108

[3] Byler S, Goldgar S, Heerboth S, Leary M, Housman G, Moulton K, Sarkar S. Genetic and epigenetic aspects of breast cancer progression and therapy. Anticancer Res. 2014;34(3):1071-7.

[4] Perou CM, Sørlie T, Eisen MB, van de Rijn M, Jeffrey SS, Rees CA, Pollack JR, Ross DT, Johnsen H, Akslen LA, Fluge O, Pergamenschikov A, Williams C, Zhu SX, Lønning PE, Børresen-Dale AL, Brown PO, Botstein D. Molecular portraits of human breast tumours. Nature. 2000;406(6797):747-52. doi: 10.1038/35021093

[5] Hsiao YH, Chou MC, Fowler C, Mason JT, Man YG. Breast cancer heterogeneity: Mechanisms, proofs, and implications. J Cancer. 2010;1:6-13.

[6] Viale G. The current state of breast cancer classification. Ann Oncol. 2012;23(Suppl 10):x207-10. doi: 10.1093/annonc/mds326

[7] Cancer Genome Atlas Network. Comprehensive molecular portraits of human breast tumours. Nature. 2012;490(7418):61-70. doi: 10.1038/nature11412

[8] Kim HJ, Yang KM, Park YS, Choi YJ, Yun JH, Son CH, Suh HS, Jeong MH, Jo WS. The novel resveratrol analogue HS-1793 induces apoptosis via the mitochondrial pathway in murine breast cancer cells. Int J Oncol. 2012;41(5):1628-34. doi: 10.3892/ijo.2012.1615

[9] Song H, JungJI, Cho HJ, Her S, Kwon SH, Yu R, Kang YH, Lee KW, Park JH. Inhibition of tumor progression by oral piceatannol in mouse 4T1 mammary cancer is associated with decreased angiogenesis and macrophage infiltration. J NutrBiochem. 2015;26(11):1368-78. doi: 10.1016/j.jnutbio.2015.07.005

[10] Jeyabalan J, Aqil F, Munagala R, Annamalai L, Vadhanam MV, Gupta RC. Chemopreventive and therapeutic activity of dietary blueberry against estrogen-mediated breast cancer. J Agric Food Chem. 2014;62(18):3963-71. doi: 10.1021/jf403734j

[11] Mazzoni L, Perez-Lopez P, Giampieri F, Alvarez-Suarez JM, Gasparrini M, Forbes-Hernandez TY, Quiles JL, Mezzetti B, Battino M. The genetic aspects of berries: From field to health. J Sci Food Agric. 2016;96(2):365-71. doi: 10.1002/jsfa.7216

[12] Mortaş H, Sanlier N. Nutritional evaluation of commonly consumed berries: Composition and health effects. Fruits. 2017;72 (1):5-23. doi: 10.17660/th 2017/72.1.1

[13] Di Vittori L, Mazzoni L, Battino M, Mezzetti B. Pre-harvest factors influencing the quality of berries. Sci Hort. 2018;233:310-22. doi: 10.1016/j.scienta.2018.01.058

[14] Skrovankova S, Sumczynski D, Mlcek J, JurikovaT, Sochor J. Bioactive Compounds and Antioxidant Activity in Different Types of Berries. Int J Mol Sci. 2015;16(10):24673-706. doi: 10.3390/ijms 161024673 
[15] Joseph SV, Edirisinghe I, Burton-Freeman BM. Berries: Anti-inflammatory effects in humans. J Agric Food Chem. 2014;62(18):3886903. doi: 10.1021/jf4044056

[16] Borges G, Roowi S, Rouanet JM, Duthie GG, Lean ME, Crozier A. The bioavailability of raspberry anthocyanins and ellagitannins in rats. Mol NutrFood Res. 2007;51(6):714-25. doi: 10.1002/mnfr.200700024

[17] González-Barrio R, Borges G, Mullen W, Crozier A. Bioavailability of anthocyanins and ellagitannins following consumption of raspberries by healthy humans and subjects with an ileostomy. J Agric Food Chem. 2010;58(7):3933-9. doi: 10.1021/jf100315d

[18] Ludwig IA, Mena P, Calani L, Borges G, Pereira-Caro G, Bresciani L, Del Rio D, Lean ME, Crozier A. New insights into the bioavailability of red raspberry anthocyanins and ellagitannins. Free Radic Biol Med. 2015;89:758-69. doi: 10.1016/j.freeradbiomed.2015.10.400

[19] Prior RL. Anthocyanins: Understanding their absorption and metabolism, in: J.P.E. Spencer, A. Crozier (Eds.), Flavonoids and related compounds. Bioavailability and function, CRC Press, Boca Raton, FL, 79-92, 2012.

[20] Kay CD, Mazza GJ, Holub BJ. Anthocyanins exist in the circulation primarily as metabolites in adult men. J Nutr. 2005;135(11):2582-8. doi: $10.1093 / \mathrm{jn} / 135.11 .2582$

[21] McGhie TK, Walton MC. The bioavailability and absorption of anthocyanins: Towards a better understanding. Mol Nutr Food Res. 2007;51(6):702-13. doi: 10.1002/mnfr.200700092

[22] Devasagayam TP, Tilak JC, Boloor KK, Sane KS, Ghaskadbi SS, Lele RD. Free radicals and antioxidants in human health: Current status and future prospects. J Assoc Physicians India. 2004;52:794-804.

[23] Birt DF, Hendrich S, Wang W. Dietary agents in cancer prevention: Flavonoids and isoflavonoids. PharmacolTher. 2001;90(2-3): 157-77.

[24] Imanshahidi M, Hosseinzadeh H. Pharmacological and therapeutic effects of Berberis vulgaris and its active constituent, berberine. Phytother Res. 2008;22(8):999-1012. doi: 10.1002/ptr.2399

[25] Pierpaoli E, Arcamone AG, Buzzetti F, Lombardi P, Salvatore C, Provinciali M. Antitumor effect of novel berberine derivatives in breast cancer cells. Biofactors. 2013;39(6):672-9. doi: 10.1002/biof.1131

[26] Mazza G, Cacace JE, Kay CD. Methods of analysis for anthocyanins in plants and biological fluids. J AOAC Int. 2004;87(1):129-45.

[27] Seo EY. Delphinidin inhibits cell proliferation and induces apoptosis in MDA-MB-231 human breast cancer cell lines. Nutr Res Pract. 2009;3(4):265-71. doi: 10.4162/nrp.2009.3.4.265

[28] Ci Y, Zhang Y, Liu Y, Lu S, Cao J, Li H, Zhang J, Huang Z, Zhu X, Gao J, Han M. Myricetin suppresses breast cancer metastasis through down-regulating the activity of matrix metalloproteinase (MMP)-2/9. Phytother Res. 2018;32(7):1373-81. doi: 10.1002/ptr.6071

[29] Roupe KA, Remsberg CM, Yáñez JA, DaviesNM. Pharmacometrics of stilbenes: Seguing towards the clinic. Curr Clin Pharmacol. 2006;1(1):81-101.

[30] Rezaei-Sadabady R, Eidi A, Zarghami N, Barzegar A. Intracellular ROS protection efficiency and free radical-scavenging activity of quercetin and quercetin-encapsulated liposomes. Artif Cells NanomedBiotechnol. 2016;44(1):128-34. doi: 10.3109/21691401.2014.926456

[31] Kim JA, Kim DH, Hossain MA, Kim MY, Sung B, Yoon JH, Suh H, Jeong TC, Chung HY, Kim ND. HS-1793, a resveratrol analogue, induces cell cycle arrest and apoptotic cell death in human breast cancer cells. Int J Oncol. 2014;44(2):473-80. doi: 10.3892/ijo.2013.2207

[32] Saluzzo J, Hallman KM, Aleck K, Dwyer B, Quigley M, Mladenovik V, Siebert AE, Dinda S. The regulation of tumor suppressor protein, p53, and estrogen receptor $(E R \alpha)$ by resveratrol in breast cancer cells. Genes Cancer. 2016;7(11-12):414-25. doi: $10.18632 /$ genesandcancer. 125

[33] Visioli F. The resveratrol fiasco. Pharmacol Res. 2014;90:87. doi: 10.1016/j.phrs.2014.08.003

[34] Ronghe A, Chatterjee A, Singh B, Dandawate P, Murphy L, Bhat NK, Padhye S, Bhat HK. Differential regulation of estrogen receptors $\alpha$ and $\beta$ by 4-(E)- $\{(4$-hydroxyphenylimino) $\}$-methylbenzene,1,2-diol $\}$, a novel resveratrol analog. J Steroid Biochem Mol Biol. 2014;144(Pt B):500-12. doi: 10.1016/j.jsbmb.2014.09.015

[35] Okamoto H, Matsukawa T, Doi S, Tsunoda T, Sawata Y, Naemura M, Ohnuki K, Shirasawa S, Kotake Y. A novel resveratrol derivative selectively inhibits the proliferation of colorectal cancer cells with KRAS mutation. Mol Cell Biochem. 2018;442(1-2):39-45. doi: 10.1007/s11010-017-3191-x

[36] Hata Y, Etoh T, Inomata M, Shiraishi N, NishizonoA, Kitano S. Efficacy of oncolytic reovirus against human breast cancer cells. Oncol Rep. 2008;19(6):1395-8.

[37] Afrin S, Giampieri F, Gasparrini M, Forbes-Hernandez TY, Varela-López A, Quiles JL, Mezzetti B, Battino M. Chemopreventive and Therapeutic Effects of Edible Berries: A Focus on Colon Cancer Prevention and Treatment. Molecules. 2016;21(2):169. doi: $10.3390 /$ molecules 21020169 
[38] Battino M, Forbes-Hernandez TY, Gasparrini M, Afrin S, Cianciosi D, Zhang J, Manna PP, Reboredo-Rodríguez P, Varela-Lopez A, Quiles JL, Mezzetti B, Bompadre S, Xiao J, Giampieri F. Relevance of functional foods in the Mediterranean diet: The role of olive oil, berry and honey in the prevention of cancer and cardiovascular diseases. Crit Rev Food Sci Nutr, In press. (doi: 10.1080/10408398.2018.1526165).

[39] Stoner GD. Whole Food Approach to Cancer Prevention: Berries as an Example. Progress in Chemistry -Beijing. 2013;25(9):1480-91.

[40] Aqil F, Vadhanam MV, Jeyabalan J, Cai J, Singh IP, Gupta RC. Detection of anthocyanins/anthocyanidins in animal tissues. J Agric Food Chem. 2014 7;62(18):3912-8. doi: 10.1021/jf500467b

[41] Wang LS, Stoner GD. Anthocyanins and their role in cancer prevention. Cancer Lett. 2008;269(2):281-90. doi: 10.1016/j.canlet.2008.05.020

[42] Forman V, Haladová M, Grančai D, Ficková M. Antiproliferative Activities of Water Infusions from Leaves of Five Cornus L. Species. Molecules. 2015;20(12):22546-52. doi: 10.3390/molecules201219786

[43] Wawruszak A, Czerwonka A, Okła K, Rzeski W. Anticancer effect of ethanol Lyciumbarbarum (Goji berry) extract on human breast cancer T47D cell line. Nat Prod Res. 2016;30(17):1993-6. doi: 10.1080/14786419.2015.1101691

[44] Cumaoğlu A, Bekçi H, ÖztürkE, Yerer MB, Baldemir A, Bishayee A. Goji Berry Fruit Extracts Suppress Proliferation of TripleNegative Breast Cancer Cells by Inhibiting EGFR-Mediated ERK/MAPK and PI3K/Akt Signaling Pathways. Natural Product Communications. 2018;13(6):701-6.

[45] Pace E, Jiang Y, Clemens A, Crossman T, Rupasinghe HPV. Impact of Thermal Degradation of Cyanidin-3-O-Glucoside of Haskap Berry on Cytotoxicity of Hepatocellular Carcinoma HepG2 and Breast Cancer MDA-MB-231 Cells. Antioxidants (Basel). 2018;7(2). pii: E24. doi: 10.3390/antiox7020024

[46] Ayyanar M, Subash-Babu P, Ignacimuthu S. Syzygiumcumini (L.) Skeels., a novel therapeutic agent for diabetes: Folk medicinal and pharmacological evidences. Complement Ther Med. 2013;21(3):232-43. doi: 10.1016/j.ctim.2013.03.004

[47] Aqil F, Gupta A, MunagalaR, Jeyabalan J, Kausar H, Sharma RJ, Singh IP, Gupta RC. Antioxidant and antiproliferative activities of anthocyanin/ellagitannin-enriched extracts from Syzygiumcumini L. (Jamun, the Indian Blackberry). Nutr Cancer. 2012;64(3):428-38. doi: 10.1080/01635581.2012.657766

[48] Aqil F, Jeyabalan J, Munagala R, Singh IP, Gupta RC. Prevention of hormonal breast cancer by dietary jamun. Mol Nutr Food Res. 2016;60(6):1470-81. doi: 10.1002/mnfr.201600013

[49] Moreno L, Bello R, Beltrán B, Calatayud S, Primo-Yúfera E, Esplugues J. Pharmacological screening of different Juniperusoxycedrus L. extracts. Pharmacol Toxicol. 1998;82(2):108-12.

[50] De Marino S, FestaC, Zollo F, Rusolo F, Capone F, Guerriero E, Costantini S, De Felice V, Iorizzi M. Phytochemical profile of Juniperusoxycedrus ssp. oxycedrus berries: A new monoterpene glucoside and evaluation of the effects on cancer cell lines. Phytochemistry Letters. 2014;10:152-9.doi: 10.1016/j.phytol.2014.08.015

[51] Zhang L, Shamaladevi N, Jayaprakasha GK, Patil BS, Lokeshwar BL. Polyphenol-rich extract of Pimentadioica berries (Allspice) kills breast cancer cells by autophagy and delays growth of triple negative breast cancer in athymic mice. Oncotarget. 2015;6(18):16379-95. doi: 10.18632/oncotarget.3834

[52] Chang LC, Sang-Ngern M, Pezzuto JM, Ma C. The Daniel K. Inouye College of Pharmacy Scripts: Poha Berry (Physalis peruviana) with Potential Anti-inflammatory and Cancer Prevention Activities. Hawaii J Med Public Health. 2016;75(11):353-9.

[53] George BP, Abrahamse H, Hemmaragala NM. Phenolics from Rubusfairholmianus induces cytotoxicity and apoptosis in human breast adenocarcinoma cells. Chem Biol Interact. 2017;275:178-88. doi: 10.1016/j.cbi.2017.08.005

[54] Guo R, Chang X, Guo X, Brennan CS, Li T, Fu X, Liu RH. Phenolic compounds, antioxidant activity, antiproliferative activity and bioaccessibility of Sea buckthorn (Hippophaërhamnoides L.) berries as affected by in vitro digestion. Food Funct. 2017;8(11):4229-40. doi: $10.1039 / \mathrm{c} 7$ fo00917h

[55] Khan HJ, Ahmad MK, Khan AR, Rastogi N, Mahdi AA, Ansari JA, Fatima N, Satyanarayan GNV. Identification of Anticancer and Antioxidant phytoconstituents from chloroform fraction of Solanum nigrum L. berries using GC-MS/MS analysis. Indian J Exp Biol. 2016;54(11):774-82.

[56] Amatori S, Mazzoni L, Alvarez-Suarez JM, Giampieri F, Gasparrini M, Forbes-Hernandez TY, Afrin S, Errico Provenzano A, Persico G, Mezzetti B, Amici A, Fanelli M, Battino M. Polyphenol-rich strawberry extract (PRSE) shows in vitro and in vivo biological activity against invasive breast cancer cells. Sci Rep. 2016;6:30917. doi: 10.1038/srep30917

[57] Mazzoni L, Alvarez Suarez JM, Giampieri F, Gasparrini M, Forbes Hernandez TY, Mezzetti B. Evaluation of strawberry (Fragaria $\times$ ananassa Duch.) Alba sensorial and nutritional quality, and its in vitro effects against human breast cancer cells viability. Acta Hortic. 2017;1156:379-88.doi: 10.17660/ActaHortic.2017.1156.57

[58] Ahmad R, Fatima A, Srivastava AN, Khan MA. Evaluation of apoptotic activity of Withaniacoagulans methanolic extract against human breast cancer and Vero cell lines. J Ayurveda Integr Med. 2017;8(3):177-83. doi: 10.1016/j.jaim.2017.01.001

[59] Abdel-Fattah WI, Eid MM, Abd El-Moez SI, Mohamed E, Ali GW. Synthesis of biogenic Ag@Pd Core-shell nanoparticles having anti-cancer/anti-microbial functions. Life Sci. 2017;183:28-36. doi: 10.1016/j.1fs.2017.06.017 
[60] Kędzierska M, Malinowska J, Kontek B, Kołodziejczyk-Czepas J, Czernek U, Potemski P, Piekarski J, Jeziorski A, Olas B. Chemotherapy modulates the biological activity of breast cancer patients plasma: The protective properties of black chokeberry extract. Food Chem Toxicol. 2013;53:126-32. doi: 10.1016/j.fct.2012.11.042

[61] Link LB, Canchola AJ, Bernstein L, Clarke CA, Stram DO, Ursin G, Horn-Ross PL. Dietary patterns and breast cancer risk in the California Teachers Study cohort. Am J Clin Nutr. 2013;98(6):1524-32. doi: 10.3945/ajen.113.061184

[62] Fung TT, Chiuve SE, Willett WC, Hankinson SE, Hu FB, Holmes MD. Intake of specific fruits and vegetables in relation to risk of estrogen receptor-negative breast cancer among postmenopausal women. Breast Cancer Res Treat. 2013;138(3):925-30. doi: 10.1007/s10549-013-2484-3 